\title{
Changes in soil carbon, nitrogen and sulphur content as influenced by liming and nitrogen fertilization of three energy crops
}

\author{
GINTARAS ŠIAUDINIS ${ }^{1}$, INGA LIAUDANSKIENE ${ }^{2}$, ALVYRA ŠLEPETIENË $\dot{ }^{2}$
}

${ }^{I}$ Véžaičiai Branch of the Lithuanian Research Centre for Agriculture and Forestry (LAMMC), Klaipéda, Lithuania, gintaras.siaudinis@vezaiciai.lzi.lt (correspondingauthor)

${ }^{2}$ Institute of Agriculture, Lithuanian Research Centre for Agriculture and Forestry, Akademija, Kèdainiai district, Lithuania

\begin{abstract}
An experiment with three perennial energy crops - common mugwort (Artemisia vulgaris L.), cup plant (Silphium perfoliatum L.) and virginia mallow (Sida hermaphrodita Rusby) has been carried out in Lithuania $\left(55^{\circ} 43^{\prime} \mathrm{N}\right.$, $\left.21^{\circ} 28^{\prime} \mathrm{E}\right)$ in order to evaluate the effect of liming and nitrogen fertilization on soil total carbon $\left(\mathrm{C}_{\text {tot }}\right)$, nitrogen $\left(\mathrm{N}_{\text {tot }}\right)$ and sulphur $\left(\mathrm{S}_{\text {tot }}\right)$ contents. The soil of the experimental site is a naturally acid moraine loam Bathygleyic Dystric Glossic Retisol. Soil composition was analysed in two consequent years 2010 and 2011. The application of the highest rate $\left(6 \mathrm{tha}^{-1}\right)$ of the lime material increased $\mathrm{C}_{\text {tot }}, \mathrm{N}_{\text {tot }}$ and $\mathrm{S}_{\text {tot }}$ concentration in the top 0-30 cm soil layer. The soil under cup plant and virginia mallow accumulated a higher concentration of $\mathrm{N}_{\text {tot }}$ and $\mathrm{S}_{\text {tot }}$ compared to that under common mugwort. $\mathrm{N}$ fertilization significantly increased $\mathrm{C}_{\text {tot }}$ content, but had no significant impact on soil $\mathrm{N}_{\text {tot }}$ and $\mathrm{S}_{\text {tot }}$ changes.
\end{abstract}

Keywords: carbon, common mugwort, cup plant, nitrogen, soil sulphur, virginia mallow

\section{YFIRLIT}

Tilraun með prjár orkuplöntur; malurt (Artemisia vulgaris L.), bollafífil (Silphium perfoliatum L.) og moskusrós (Sida hermaphrodita Rusby) var gerð í Litháen $\left(55^{\circ} 43^{\prime} \mathrm{N}, 21^{\circ} 28^{\prime} \mathrm{E}\right)$ til að meta áhrif kölkunar og köfnunarefnisáburðargjafar á heildar kolefni $\left(\mathrm{C}_{\text {tot }}\right)$, köfnunarefni $\left(\mathrm{N}_{\text {tot }}\right)$ og brennistein $\left(\mathrm{S}_{\text {tot }}\right)$ í jarðvegi. Jarðvegur tilraunasvæðisins var á fínkorna jökulruðningi sem er súr að eðlisfari (Bathygleyic Dystric Glossic Retisol). Jarðvegur var greindur tvö ár í röð, 2010 og 2011. Hæsti skammtur af kalki ( $\left.6 \mathrm{t} \mathrm{ha}^{-1}\right)$ leiddi til pess að að $\mathrm{C}_{\text {tot }}, \mathrm{N}_{\text {tot }}$ og $\mathrm{S}_{\text {tot }}$ jukust í efstu $30 \mathrm{~cm}$ jarðvegsins. Ræktun á bollafífil og moskusrós leiddi til hækkunar á $\mathrm{N}_{\text {tot }}$ og $\mathrm{S}_{\text {tot }}$ í efri lögum jarðvegs miðað við par sem malurt var ræktuð. Köfnunarefnisáburður leiddi til marktækrar aukningar á $\mathrm{C}_{\text {tot }}$ í jarðvegi en hafði engin áhrif á $\mathrm{N}_{\text {tot }}$ og $\mathrm{S}_{\text {tot }}$ í jarðveginum.

\section{INTRODUCTION}

The main objective of the Kyoto protocol (1992) and the subsequent Doha conference (2012) was to reach an agreement to reduce global greenhouse gas (GHG) emissions. In this context, the European renewable energy directive 2009/28/EC (Directive 2009/28/ EC, 2009) provides a legislative framework for reducing GHG emissions by $20 \%$, while achieving a $20 \%$ share of energy from renewable sources by 2020 . One way to achieve this is to replace fossil fuel by renewable bioenergy fuel sources and energy crops (Clifton-Brown et al. 2007, Sarkhot et al. 2012). Energy crops are characterised by rapid growth and a large 
amount of an annual low-moisture biomass compared to trees, and consequently a very large amount of residues left in the field (BorzeckaWalker et al. 2011). Many researchers state that perennial crops allow carbon accumulation and sequestration in the soil (Sladen et al. 1991, Bransby et al. 1998, Anderson-Teixeira et al. 2009). A highly important factor for carbon sequestration in the soil is that energy crops are grown for a long time in the same field. The ability of perennial grasses to effect change in soil properties is well documented (Blanco-Canqui 2010, Follett et al. 2012), but the information about soil changes specific to crops managed for bioenergy production in Lithuanian soil and climate conditions is limited. Perennial energy crops like Panicum virgatum L., Miscanthus giganteus, Artemisia vulgaris L., Silphium perfoliatum L., Sida hermaphrodita Rusby are projected to reduce reliance on fossil fuels, reduce GHG emission and enhance the rural economy. Further, most of the land dedicated to perennial bioenergy crops should be marginal cropland in order to avoid competition with food crops, decrease water pollution and reduce wind and water erosion (Schmer et al. 2011). Perennial grasses used for energy purposes are characterized by a high yield potential, deep root systems, require low fertilization input and conservative agricultural practices (Lewandowski et al. 2003), which determine the low soil organic matter mineralization (Lemus \& Lal 2005). As a result, perennial energy grasses have the potential to accumulate $\mathrm{C}$ in the soil and diminish GHG emissions. Nitrogen fertilization stimulates root development, which in turn results in carbon accumulation (Schuman et al. 2002). Although the effects of liming on carbon sequestration are insufficiently studied, longterm experiments with perennial grasses show that lime application enhances the possibility of soil organic carbon $\left(\mathrm{C}_{\text {org }}\right)$ sequestration (Fornara et al. 2011). Soil productivity improves with increasing soil $\mathrm{C}_{\text {org }}$ content, which in turn retards the loss of $\mathrm{N}$ from fertilizer and agricultural waste (Bransby et al. 1998).

The above-ground biomass productivity, morphological and technological characteristics of the energy crops investigated in our study were explored by Jasinskas et al. (2014). We chose to evaluate the content of $\mathrm{C}_{\text {tot }}, \mathrm{N}_{\text {tot }}$ and $\mathrm{S}_{\text {tot }}$ due to their direct contribution to soil basic characteristics, such as aggregation and aggregate stability, soil buffering capacity, water holding capacity, fertility and soil biological quality.

The objective of this study was to ascertain the effect of unconventional agricultural crops - common mugwort, cup plant and virginia mallow - on soil quality in Western Lithuania's Bathygleyic Dystric Glossic Retisol.

\section{MATERIALS AND METHODS}

A field experiment has been conducted in the Vèžaičiai Branch (LAMMC) $\left(55^{\circ} 43^{\prime} \mathrm{N}, 21^{\circ} 28^{\prime} \mathrm{E}\right)$ since 2008. The soil of the experimental site is a naturally acid moraine loam Bathygleyic Dystric Glossic Retisol (WRB 2014). Before the experiment, topsoil $\mathrm{pH}(1 \mathrm{M} \mathrm{KCl,} \mathrm{w/v} \mathrm{1:2.5)}$ ranged between 4.25 and 4.85 , and the content of available phosphorus (P) and potassium (K) determined by Egner-Riehm-Domingo ALmethod (Egner et al. 1960) was $15-52 \mathrm{mg} \mathrm{kg}^{-1}$ and $116-173 \mathrm{mg} \mathrm{kg}^{-1}$, respectively; hydrolytic acidity values determined according to Kappen method (Kappen, 1929) were 35.1-62.1 cmol $\mathrm{kg}^{-1}$; the content of exchangeable aluminium (Al), determined according to the Sokolov method (Barnhisel \& Bertsch, 1982) using $1 \mathrm{M}$ $\mathrm{KCl}$ for displacing $\mathrm{Al}$ ions, ranged between 10.7 and $50.9 \mathrm{mg} \mathrm{kg}^{-1}$.

The experiment was laid out in a two-factor design, including 3 levels of liming: without liming, $3 \mathrm{t} \mathrm{ha}^{-1}$ and $6 \mathrm{t} \mathrm{ha}^{-1}$ of liming material, and two levels of nitrogen $(\mathrm{N})$ fertilization: 0 and $120 \mathrm{~kg} \mathrm{ha}^{-1}$. The experimental plots were limed with Opokos (powdered limestone), which contains up to $30 \%$ of $\mathrm{CaCO}_{3}$ on the $20^{\text {th }}$ of April, 2008. The seedlings of common mugwort were planted on the $27^{\text {th }}$ of May, and seedlings of cup plant were planted at a 2-3 leaf stage on the $3^{\text {rd }}$ of June, 2008.

The experimental site was divided into three strips with different soil $\mathrm{pH}$ levels. All nitrogen treatments were arranged randomly with three replications for each $\mathrm{pH}$ (different liming) 
background. Since 2009, mineral fertilization has been applied each year before the beginning of the test crops' growth in mid-April. Ammonium nitrate was applied as $\mathrm{N}$ fertilizer. Single superphosphate and potassium chloride were used as $\mathrm{P}$ and $\mathrm{K}$ fertilizers. The $120 \mathrm{~kg} \mathrm{ha}^{-1}$ $\mathrm{N}$ rate was split and applied twice $(60+60 \mathrm{~kg}$ $\mathrm{ha}^{-1}$ ), in the middle of April and in the beginning of July. The annual rate of phosphorus and potassium fertilization was $26 \mathrm{~kg} \mathrm{P} \mathrm{ha}^{-1}$ and 50 $\mathrm{kg} \mathrm{K} \mathrm{ha-1}$ respectively.

Eight sub-samples per plot were taken randomly with a steel auger from $0-30 \mathrm{~cm}$ depth and a composite sample was formed for each plot. The samples were collected in 2010 and 2011 at the end of plant vegetation (beginning of October) from two limed strips in the 0 and $120 \mathrm{~kg} \mathrm{ha}^{-1} \mathrm{~N}$ fertilization treatments from three field replicates. All samples were air-dried, and visible roots and plant residues were manually removed. Then the samples were crushed, sieved through a 2-mm sieve and homogeneously mixed. For the analysis of soil $\mathrm{C}_{\text {tot }}, \mathrm{N}_{\text {tot }}$ and $\mathrm{S}_{\text {tot }}$ an aliquot of the soil samples was passed through a $0.25-\mathrm{mm}$ sieve. The soil $\mathrm{C}_{\text {tot }}, \mathrm{N}_{\text {tot }}$ and $\mathrm{S}_{\text {tot }}$ contents were determined by a dry combustion (Dumas) method using a fully automatic CNS analyser Vario EL IIII (Elementar, Germany). All data were expressed on an oven-dry basis.

The experimental data for all three soil parameters were statistically processed using analysis of variance (Anova) as a three factorial randomized block variant to determine significant differences between means $(* \mathrm{P}<0.05$ and $* * \mathrm{P}<0.01)$ and $L S D_{05}$ and at a 0.05 probability level (Tarakanovas \& Raudonius 2003).

\section{RESULTS}

Analysis of variance was used to evaluate the effect of crop species $(\mathrm{Cr})$, liming rate (L) and nitrogen rate $(\mathrm{N})$ and their interactions. The data are presented in Table 1. According to Fisher's criterion, crop and liming rates were determining factors affecting the contents of $\mathrm{C}_{\text {tot }}, \mathrm{N}_{\text {tot }}$, and $\mathrm{S}_{\text {tot }}$ in a naturally acid Bathygleyic Dystric Glossic Retisol $(\mathrm{P}<0.01$ and $\mathrm{P}<0.05)$. The analysis
Table 1. Fisher criterion's mean squares for organic carbon (Ctot), total nitrogen (Ntot) and total sulphur (Stot) as affected by crop species (Cr), liming (L) and nitrogen rate $(\mathrm{N})$

\begin{tabular}{lccc}
\hline Variable & $\begin{array}{c}\text { Total } \\
\text { carbon } \\
\left(\mathbf{C}_{\text {tot }}\right)\end{array}$ & $\begin{array}{c}\text { Total } \\
\text { nitrogen } \\
\left(\mathbf{N}_{\text {tot }}\right)\end{array}$ & $\begin{array}{c}\text { Total } \\
\text { sulphur } \\
\left(\mathbf{S}_{\text {tot }}\right)\end{array}$ \\
\hline Crop (Cr) & $5.99^{*}$ & $815^{*}$ & $17.5^{*}$ \\
Liming rate (L) & $4.49^{*}$ & $16.9^{*}$ & $6.69^{*}$ \\
Nitrogen rate (N) & 0.99 & 0.94 & 0.80 \\
Cr x L & $3.97^{*}$ & $13.6^{*}$ & 2.34 \\
Cr x N & 0.93 & 0.62 & 0.36 \\
L x N & 4.69 & 0.24 & 0.13 \\
Cr x L x N & 1.43 & 0.24 & 0.13 \\
\hline
\end{tabular}

* - significant at $\mathrm{P}<0.05$ level

also indicated that different crops and different liming rates had an unequal impact on the soil's chemical content. Thus, the interaction between crop species and liming rate $(\mathrm{Cr} \times \mathrm{L})$ positively influenced soil carbon $\left(\mathrm{C}_{\text {tot }}\right)$ and total nitrogen $\left(\mathrm{N}_{\text {tot }}\right)$ content $(\mathrm{P}<0.01$ and $\mathrm{P}<0.05)$. On the other hand, the effect of the nitrogen rate $(\mathrm{N})$ on the studied parameters was insignificant. The interactions of other parameters $(\mathrm{Cr} \times \mathrm{N}$, L $x$ N and $\mathrm{Cr} \times \mathrm{L} \times \mathrm{N}$ ) were also statistically insignificant.

The results shown in Figure 1 suggest that liming at a $6 \mathrm{t} \mathrm{ha}^{-1}$ rate had a positive impact on the accumulation of $\mathrm{C}_{\text {tot }}$ irrespective of energy plant species tested $(\mathrm{P}<0.01)$. After 2 years of energy crop cultivation, soil $\mathrm{C}_{\text {tot }}$ significantly increased in the $0-30 \mathrm{~cm}$ soil layer, compared with the unlimed treatment. The $\mathrm{C}_{\text {tot }}$ content increased from 8.25 to $14.16 \mathrm{~g} \mathrm{~kg}^{-1}$ under cup plant, and from 9.85 to $13.61 \mathrm{~g} \mathrm{~kg}^{-1}$ under virginia mallow. Meanwhile the effect of liming on soil $\mathrm{C}_{\text {tot }}$ content under common mugwort was insignificant. $\mathrm{N}$ fertilization significantly increased the $\mathrm{C}_{\text {tot }}$ content in the upper soil layer for all three plants.

The data from our study suggest that liming with $6 \mathrm{t} \mathrm{ha}^{-1}$ of liming material had a substantial impact on the soil $\mathrm{N}_{\text {tot }}$ increase under cup plant only (Figure 2). Conversely, the $\mathrm{N}_{\text {tot }}$ content 


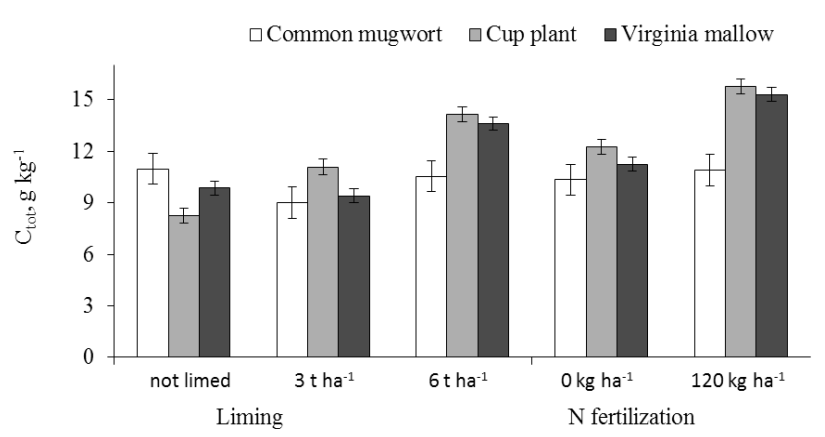

Figure 1. The content of $C_{\text {tot }}$ in the soil $(0-30 \mathrm{~cm})$ under common mugwort, cup plant and virginia mallow as affected by liming and fertilization. Average of 2010-2011.

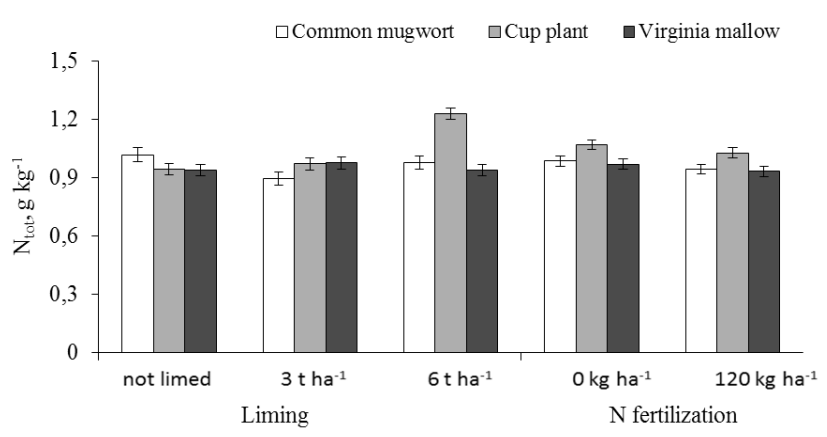

Figure 2. The content of $\mathrm{N}_{\text {tot }}$ in the soil $(0-30 \mathrm{~cm})$ under common mugwort, cup plant and virginia mallow as affected by liming and fertilization. Average of 2010-2011.

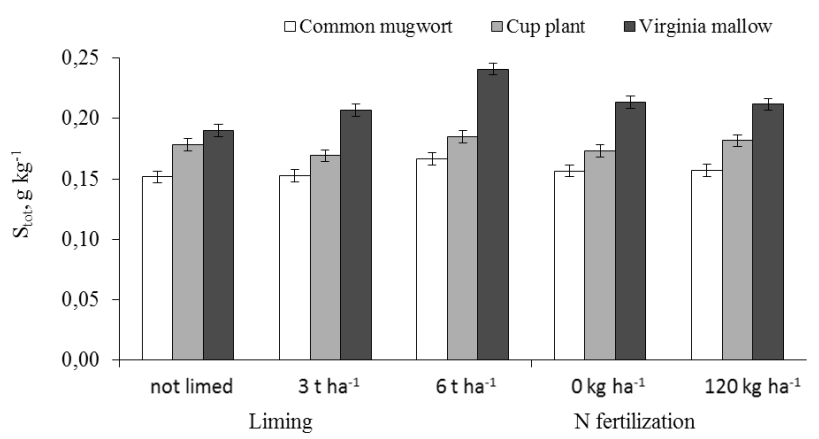

Figure 3. The content of $S_{\text {tot }}$ in the soil $(0-30 \mathrm{~cm})$ under common mugwort, cup plant and virginia mallow as affected by liming and fertilization. Average of 2010-2011. decreased from 1.02 (without liming) to 0.898 (liming with $6 \mathrm{t} \mathrm{ha}^{-1}$ ) under common mugwort. The $\mathrm{N}_{\text {tot }}$ content under virginia mallow remained stable. The highest $\mathrm{N}_{\text {tot }}$ content was observed under cup plant. However, no significant changes in soil $\mathrm{N}_{\text {tot }}$ resulting from the $\mathrm{N}$ fertilization were established, possibly due to the ability of plants to utilise soil nutrients.

No S fertilizer was applied prior to or during the experimental period. The concentration of $\mathrm{S}_{\text {tot }}$ was substantially higher under virginia mallow compared with common mugwort and cup plant (Figure 3). The highest $\mathrm{S}_{\text {tot }}$ content was found in the soil applied with $6 \mathrm{t} \mathrm{ha}^{-1}$ liming rate - from $0.17 \mathrm{~g} \mathrm{~kg}^{-1}$ under common mugwort to $0.24 \mathrm{~g} \mathrm{~kg}^{-1}$ under virginia mallow. $\mathrm{N}$ fertilization had no significant effect on $\mathrm{S}_{\text {tot }}$ content.

The experimental results indicated that liming improves the rooting system (particularly of cup plant and virginia mallow), which in turn enhances the uptake of mobile nutrients (including $\mathrm{N}$ and $\mathrm{S}$ ) from deeper soil layers. In the soil under cup plant, soil liming tended to decrease $\mathrm{C}_{\text {tot }}: \mathrm{N}_{\text {tot }}$ ratio from 15.7 to 10.4 ; meanwhile $120 \mathrm{~kg} \mathrm{ha}^{-1} \mathrm{~N}$ application had the opposite tendency. It seems that neither liming nor $\mathrm{N}$ application had significant impact on $\mathrm{C}_{\text {tot }}: \mathrm{N}_{\text {tot }}$ ratio under the other two crops tested - common mugwort and virginia mallow (Table 2). The data of the current study (Table 2) showed that the $\mathrm{C}_{\text {tot }}: \mathrm{S}_{\text {tot }}$ ratio also varied in response to liming, $\mathrm{N}$ fertilization, as well as cultivated plant species. In all the cases, the application of $3 \mathrm{t} \mathrm{ha}^{-1}$ liming and $120 \mathrm{~kg} \mathrm{ha}^{-1} \mathrm{~N}$ fertilization caused a significant decrease in the $\mathrm{C}_{\text {tot }}: \mathrm{S}_{\text {tot }}$ ratio. Although statistically significant, the influence of liming and $120 \mathrm{~kg} \mathrm{ha}^{-1} \mathrm{~N}$ application on $\mathrm{N}_{\text {tot }}: \mathrm{S}_{\text {tot }}$ ratio was less obvious. Soil $\mathrm{C}_{\text {tot }}$ content positively correlated with $\mathrm{C}_{\text {tot }}: \mathrm{N}_{\text {tot }}$ ratio $(+0.92$ 
Table 2. The ratios of $\mathrm{C}_{\text {tot }}: \mathrm{N}_{\text {tot }}, \mathrm{C}_{\text {tot }}: \mathrm{S}_{\text {tot }}$ and $\mathrm{N}_{\text {tot }}: \mathrm{S}_{\text {tot }}$ in the soil $(0-30 \mathrm{~cm})$ under common mugwort, cup plant and virginia mallow as affected by liming and fertilization. Average of 2010-2011. Different letters indicate significant differences $(\mathrm{P}<0.05)$.

\begin{tabular}{|c|c|c|c|c|c|c|c|c|c|}
\hline Factor & 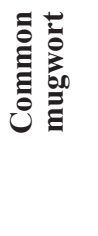 & 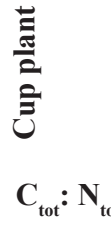 & 爱 & 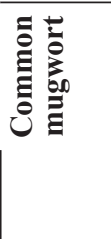 & 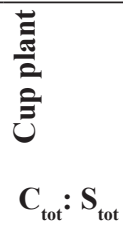 & 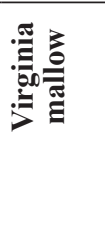 & 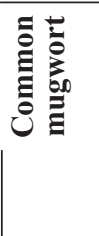 & 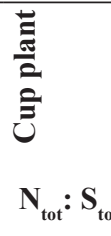 & 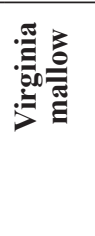 \\
\hline \multicolumn{10}{|c|}{ Liming $\mathrm{ha}^{-1} \mathrm{CaCO}_{3}$} \\
\hline Not limed & $10.5 \mathrm{a}$ & $15.7 \mathrm{a}$ & $10.3 \mathrm{a}$ & $106.7 \mathrm{a}$ & $110.8 \mathrm{a}$ & $67.1 \mathrm{a}$ & $9.60 \mathrm{a}$ & $7.08 \mathrm{a}$ & $6.43 \mathrm{a}$ \\
\hline $3 \mathrm{tha}^{-1}$ & $10.0 \mathrm{a}$ & $11.5 \mathrm{~b}$ & $9.83 \mathrm{~b}$ & $79.0 \mathrm{~b}$ & $95.5 \mathrm{~b}$ & $52.4 \mathrm{c}$ & $7.93 \mathrm{~b}$ & $7.95 \mathrm{a}$ & $5.34 \mathrm{~b}$ \\
\hline $6 \mathrm{tha}^{-1}$ & $10.4 \mathrm{a}$ & $10.4 \mathrm{~b}$ & $11.5 \mathrm{c}$ & $76.9 \mathrm{~b}$ & $93.5 \mathrm{~b}$ & $60.8 \mathrm{~b}$ & $7.72 b$ & $9.89 \mathrm{~b}$ & $5.27 \mathrm{~b}$ \\
\hline$L S D_{05}$ & 0.52 & 2.47 & 0.25 & 13.5 & 9.47 & 7.54 & 0.98 & 1.16 & 0.46 \\
\hline \multicolumn{10}{|c|}{ Nitrogen fertilization $\mathrm{kg} \mathrm{ha-l}$} \\
\hline $0 \mathrm{~kg} \mathrm{ha}^{-1}$ & $10.3 \mathrm{a}$ & $11.7 \mathrm{a}$ & $10.7 \mathrm{a}$ & $93.3 \mathrm{a}$ & $95.5 \mathrm{a}$ & $63.3 \mathrm{a}$ & $8.89 \mathrm{a}$ & $8.97 \mathrm{a}$ & $5.91 \mathrm{a}$ \\
\hline $120 \mathrm{~kg} \mathrm{ha}^{-1}$ & $10.4 \mathrm{a}$ & $13.4 \mathrm{a}$ & $10.4 \mathrm{~b}$ & $81.8 \mathrm{~b}$ & $81.7 \mathrm{~b}$ & $56.9 \mathrm{~b}$ & $7.94 \mathrm{~b}$ & $7.64 \mathrm{~b}$ & $5.46 \mathrm{a}$ \\
\hline$L S D_{05}$ & 0.36 & 1.75 & 0.18 & 9.53 & 6.63 & 5.33 & 0.69 & 0.82 & 0.65 \\
\hline
\end{tabular}

for common mugwort, and +0.87 for virginia mallow). In all cases, $\mathrm{S}_{\text {tot }}$ content in the soil negatively correlated with $\mathrm{C}_{\text {tot }}: \mathrm{S}_{\text {tot }}$ ratio $(-0.85$ for common mugwort, -0.85 for cup plant and -0.88 for virginia mallow), and with $\mathrm{N}_{\text {tot }}: \mathrm{S}_{\text {tot }}$ ratio (-0.91 for common mugwort, -0.91 for cup plant, and -0.93 for virginia mallow).

\section{DISCUSSION}

The potential of herbaceous energy crops to contribute carbon to the soil has been demonstrated by numerous authors (Lemus \& Lal 2005, Clifton-Brown et al. 2007, AndersonTeixeira et al. 2009, Blanco-Canqui 2010, Schmer et al. 2011, Borzecka-Walker et al. 2011, Follett et al. 2012, Sarkhot et al. 2012). The soil cations influenced the accumulation and sequestration of $\mathrm{C}_{\text {tot }}$ because high concentration of cations protected $\mathrm{C}_{\text {tot }}$ against decomposition (Manna et al. 2007, Morris et al. 2007). The calcium cations were especially important because their high concentration was introduced into the soil with liming. Soil $\mathrm{C}_{\text {tot }}$ tended to decline due to $\mathrm{N}$ fertilizer use.
Higher $\mathrm{C}_{\text {tot }}$ contents were recorded in cup plant and virginia mallow treatments, compared with common mugwort treatment; however, the differences were statistically insignificant. Cup plant and virginia mallow form a larger root system in the upper soil layer, which enhances $\mathrm{C}_{\text {tot }}$ accumulation and improves soil fertility. Thus, both means had a significant impact on the transformation of plant residues in the soil, and thus on $\mathrm{C}_{\text {tot }}$ accumulation

Our data agree with the findings of other researchers suggesting that the application of lime and $\mathrm{N}$ fertilization has a positive impact on soil $\mathrm{C}_{\text {tot }}$. It has been reported that soil $\mathrm{pH}$ and $\mathrm{C}$ content increase in the rhizosphere zone in response to liming (Repšiene 2003). Besides liming, other factors may have indirect influence on soil carbon accumulation: abundant root mass of energy crops, organic residues, leaf debris, root secretions are transformed into soil organic matter, humus and other soil-related elements. The increase of soil carbon levels over longer periods occurs due to the perennially of crops and a large amount of unharvested roots. Yet, it 
may take several years before any increases are detectable (Ma et al. 2000).

Subsequently, both liming and $\mathrm{N}$ fertilization had a substantial positive effect on the aboveground biomass content (Šiaudinis et al. 2012, Jasinskas et al. 2014).

Our results corresponds to the data of many researchers, that $\mathrm{N}$ fertilization can increase $\mathrm{C}_{\text {tot }}$ because of the enhanced above-ground and below-ground biomass production (Lemus \& Lal 2005, Cliford-Braun et al. 2007, Schmer et al. 2011, Follett et al. 2012).

Sulphur (S) is also an important nutrient. However, the available of $\mathrm{S}$ in the soils of Lithuania as well as in other European countries is insufficient. Liming not only neutralizes soil acidity and improves soil chemically, but also influences $\mathrm{S}$ regime in the soil and can reduce the amount of mobile $\mathrm{S}$ in the soil by up to 7-8 times (Gurys \& Aksomaitiene 2005). An adequate $\mathrm{S}$ availability for plants depends on several factors, including moisture, temperature regimes, $\mathrm{pH}$ as well as $\mathrm{C}_{\text {tot }}: \mathrm{S}_{\text {tot }}$ and $\mathrm{N}_{\text {tot }}: \mathrm{S}_{\text {tot }}$ ratios in the soil (Sachs \& Luff 2002). A strong relationship among $\mathrm{C}_{\text {tot }}, \mathrm{N}_{\text {tot }}$ and $\mathrm{S}_{\text {tot }}$ in the noncalcareous soils has been proven by Williams et al. (1960). The soil C: $\mathrm{N}$ ratio is considered to be an important indicator which characterizes the degree of organic matter decomposition in the soil (Tejada et al. 2008, Govaerts et al. 2009). However, in our trials, longer time observations are need to evaluate the changes of $\mathrm{C}$ : $\mathrm{N}$ ratio as well as their dependence on crop species or agrotechnical means. Yet in our study, a strong relationship was established between the $\mathrm{N}_{\text {tot }}$ and $\mathrm{S}_{\text {tot }}$; however, the $\mathrm{N}_{\text {tot }}: \mathrm{S}_{\text {tot }}$ ratio was rather moderate.

By cultivating such energy crop species as miscanthus and switchgrass, which have a deep root system, the content of carbon and nitrogen has a tendency to increase in the upper soil layer (Fisher et al. 1994, Kahle et al. 2001). The use of $6 \mathrm{t} \mathrm{ha}^{-1}$ lime material had a positive impact to increase soil mineral nutrients concentrations. Overall, substantially higher concentration of $\mathrm{N}_{\text {tot }}$ and $\mathrm{S}_{\text {tot }}$ accumulated in the soil under cup plant and virginia mallow compared with that under common mugwort. In all the treatments, the effect of nitrogen fertilization had a positive impact on soil $\mathrm{C}_{\text {tot }}$ content only. The current study is ongoing.

\section{CONCLUSIONS}

According to the results of the soil analyses in the current study, irrespective of energy crops species, the application of lime material had a positive impact on increasing $\mathrm{C}_{\text {tot }}, \mathrm{N}_{\text {tot }}$ and $\mathrm{S}_{\text {tot }}$ concentrations in the top soil layer. By setting the target to reduce $\mathrm{CO}_{2}$ emissions into the atmosphere, the higher importance has $\mathrm{C}$ sequestration in soil organic matter. We expect that these long-term experiments will help to comprehensively highlight and validate the dynamics of different soil nutrients (in particular, soil carbon) in response to energy crop species grown, liming and fertilization applied.

\section{ACKNOWLEDGEMENTS}

The paper presents research findings, obtained through a long-term research programme "Productivity and sustainability of agricultural and forest soils" implemented by the Lithuanian Research Centre for Agriculture and Forestry.

\section{REFERENCES}

Anderson-Teixeira KJ, Davis SC, Masters MD \& Delucia EH 2009. Changes in soil organic carbon under biofuel crops. Global Change Bioenergy 1, 75-96.

doi: https://doi.org/10.1111/j.1757-1707.2008.01001.x

Barnhisel R \& Bertsch PM 1982. Aluminium. In: A.L. page, Miller RH \& Keeney DR (eds.). Methods of soil analysis. American Society of Agronomy, Madison, Wisconsin, USA, pp. 275300.

Blanco-Canqui H 2010. Energy crops and their implications on soil and environment. Agronomy Journal 102, 403-419.

doi: https://doi.org/10.2134/agronj2009.0333

\section{Borzecka-Walker M, Faber A, Mizak K, Pudelko}

R \& Syp A 2011. Soil carbon sequestration under bioenergy crops in Poland. In: Ozkaraova Gungor B.E. (eds.) Principles, Application and Assessment in Soil Science. Rijeka: INTECH Open Access Publisher, 151-166.

doi: https://doi.org/10.5772/1860 
Bransby DI, Mclaughlin SB \& Parrish D. 1998. A review of carbon and nitrogen balances in switchgrass grown for energy. Biomass Bioenergy 14, 379-384.

doi: https://doi.org/10.1016/S0961-9534(97)10074-5

Clifton-Brown JC, Breuer J, \& Jones MB 2007. Carbon mitigation by the energy crop. Miscanthus. Global Change Biology 13, 2296-2307. doi: https://doi.org/10.1111/j.1365-2486.2007.01438.x

Directive 2009/28/EC 2009. Directive 2009/28/EC of the European Parliament and of the Council on the promotion of the use of energy from renewable sources amending and subsequently repealing Directives 2001/77/EC and 2003/30/EC. Available at: http://old.eurlex.europa.eu/LexUriServ/ LexUriServ.do?uri=OJ:L:2009:140:0016:0062:EN :pdf

Doha Amendment to the Kyoto Protocol 2012: Available at: http://unfccc.int/files/kyoto_protocol/ application/pdf/kp_doha_amendment_english.pdf.

Egnér H, Riehm H \& Domingo W.R. 1960. Untersuchungen uber die chemische Bodenanalyse als Grundlage fur die Beurteilung des Nährstoffzustandes der Böden. II. Chemische Extraktionsmethoden zur Phosphor- und Kaliumbestimmung [Investigation of the Soil Test analysis for the assessment of Soil Nutrients. II. Chemical Methods for the extraction of Phosphorus and Kali]. Kungliga Lantbrukshögskolans Annaler 26, 199-215. [in German]

Fisher MJ, Rao IM, Ayarza CE, Lascano CE, Sanz JI, Thomas RJ \& Vera RR 1994. Carbon storage by introduced deep-rooted grasses in the South American savannas. Nature 371, 236-238. doi: https://doi.org/10.1038/371236a0

Follett RF, Vogel KP, Varvel GE, Mitchell RB \& Kimble J 2012. Soil carbon sequestration by switchgrass and no-till maize grown for bioenergy. BioEnergy Research 5, 866-875. doi: https://doi.org/10.1007/s12155-012-9198-y

Fornar DA, Steinbeiss S, McNamara NP, Gleaner G, Oakley S, Poulton PR, MacDonald AJ, \& Bardgett RD 2011. Increases in soil organic carbon sequestration can reduce the global warming potential of long-term liming to permanent grassland. Global Change Biology 17, 1925-1934. doi: https://doi.org/10.1111/j.1365-2486.2010.02328.x
Govaerts B, Verhulst N, Castellanos-Navarrete A, Sayre KD, Dixon J \& Dendooven L 2009. Conservation agriculture and soil carbon sequestration: between myth and farmer reality. Critical Reviews in Plant Sciences 28, 97-122.

doi: https://doi.org/10.1080/07352680902776358

Gurys S \& Aksomaitiene R 2005. Migration of sulphur in limed soils differing in agricultural management. Nutrient Cycling in Agroecosystems 71, 191-201. doi: https://doi.org/10.1007/s10705-004-3175-6

Ingram JSI \& Fernandes ECM 2001. Managing carbon sequestration in soils: Concepts and terminology. Agriculture, Ecosystems \& Environment 87, 111-117. doi: https://doi.org/10.1016/S0167-8809(01)00145-1

Jasinskas A, Simonavičiūtė R, Šiaudinis G, Liaudanskiené I, Antanaitis S̆, Arak M \& Olt J 2014. The assessment of common mugwort (Artemisia vulgaris L.) and cup plant (Silphium perfoliatum L.) productivity and technological preparation for solid biofuel. ZemdirbysteAgriculture 101, 19-26.

doi: https://doi.org/10.13080/z-a.2014.101.003

Kappen H 1929. Die Bodenazidität. [Soil acidity]. Springer Verlag. Berlin, 363 p. [in German]

Kahle P, Beauch S, Boelcke B, Leinweber B \& Schulten HR 2001. Cropping of Miscanthus in Central Europe: Biomass production and influence on nutrients and soil organic matter. European Journal of Agronomy 15, 171-184. doi: https://doi.org/10.1016/S1161-0301(01)00102-2

Kyoto Protocol to the United Nations Framework Convention on Climate Change. 1998. Available at: http://unfecc.int/resource/docs/convkp/kpeng. pdf

Lemus R \& Lal R 2005. Bioenergy crops and carbon sequestration. Critical Reviews in Plant Sciences 24, $1-21$. doi: https://doi.org/10.1080/07352680590910393

Lewandowski I, Scurlock JMO, Lindvall E \& Christou M 2003. The development and current status of perennial rhizomatous grasses as energy crops in the US and Europe. Biomass and Bioenergy $25,335-361$. doi: https://doi.org/10.1016/S0961-9534(03)00030-8 
Ma Z, Wood CW \& Bransby DI 2000. Soil management impacts on soil carbon sequestration by switchgrass. Biomass and Bioenergy 18, 469477.

doi: http://doi.org/10.1016/S0961-9534(00)00013-1.

Manna MC, Swarup A, Wanjari RH, Mishra B \& Shahi, DK 2007. Long-term fertilization, manure and liming effects on soil organic matter and crop yields. Soil and Tillage Research 94, 397-409. doi: https://doi.org/10.1016/j.still.2006.08.013

Morris SJ, Bohm S, Haile-Mariam S \& Paul EA 2007. Evaluation of carbon accrual in afforested agricultural soils. Global Change Biology, 13, 1145-1156.

doi: https://doi.org/10.1111/j.1365-2486.2007.01359.x

Repšienė R 2003. Lokalaus ir pakriko tręšimo veiksmingumas sėjomainos augalams rūgščiame ir pakalkintame dirvožemyje. [The efficiency of placement and broadcast fertilization on the crop rotation yield on the acid and limed soil]. Zemdirbyste-Agriculture 84, 63-82 [in Lithuanian]

Sachs PD \& Luff RT 2002. Ecological golf course management. John Wiley \& Sons, NJ, USA: Inc. Hoboken.

Sarkhot DV, Grunwald S, Ge Y \& Morgan CLS 2012. Total and available soil carbon fractions under the perennial grass Cynodon dactylon (L.) Pers and the bioenergy crop Arundo donax L. Biomass and Bioenergy 41, 122-130.

doi: https://doi.org/10.1016/j.biombioe.2012.02.015

Schmer MR, Liebig MA, Vogel KP \& Mitchell RB 2011. Field-scale soil property changes under switchgrass managed for bioenergy. Global Change Biology 3, 439-448. doi: https://doi.org/10.1111/j.1757-1707.2011.01099.x

Schuman GE, Janzen HH, \& Herrick JE 2002. Soil carbon dynamics and potential carbon sequestration by rangelands. Environmental Pollution 116, 391-396.

doi: https://doi.org/10.1016/S0269-7491(01)00215-9

Šiaudinis G, Jasinskas A, Šlepetienė A, \& Karčauskienė D 2012. The evaluation of biomass and energy productivity of common mugwort (Artemisia vulgaris L.) and cup plant (Silphium perfoliatum L.) in Albeluvisol. ZemdirbysteAgriculture 99, 357-362.

Sladen SE, Bransby DI, \& Aiken GE 1991. Biomass yield, composition and production costs for eight switchgrass varieties in Alabama. Biomass and Bioenergy 1, 119-122.

doi: https://doi.org/10.1016/0961-9534(91)90034-A

Tarakanovas P \& Raudonius S 2003. Agronominiu tyrimų duomenų statistinè analizè, taikant kompiuterines programas ANOVA, STAT, SPLITPLOT iš paketo SELEKCIJA ir IRRISTAT [The statistical analysis of agronomic research data using the software programs ANOVA, STAT and SPLIT-PLOT from package Selekcija and Irristat]. Akademija, Kèdainių r., 56 p. [in Lithuanian]

Tejada M, Gonzalez JL, García-Martínez AM \& Parrado J 2008. Effects of different green manures on soil biological properties and maize yield. Bioresource Technology 99, 1758-1767. doi: https://doi.org/10.1016/j.biortech.2007.03.052

Williams CH, Williams EG \& Scott NM 1960. Carbon, nitrogen, sulphur, and phosphorus in some scottish soils. Journal of Soil Science 11, 334-346. doi: https://doi.org/10.1111/j.1365-2389.1960.tb01089.x

Manuscript received 31 August 2016 Accepted 18 April 2017 